\title{
VALIDATION OF THE COMMUNITY OF INQUIRY SURVEY (SPANISH VERSION) AT UNED COURSES
}

\author{
Inés Gil-Jaurena, Daniel Domínguez Figaredo, Belen Ballesteros Velázquez, Javier Morentin \\ Encina, Universidad Nacional de Educación a Distancia (UNED), Spain
}

\begin{abstract}
The paper covers the validation process of the Community of Inquiry (CoI) survey in its Spanish version. This task was undertaken by a group of researchers - the CO-Lab teaching innovation group - at the Universidad Nacional de Educación a Distancia (UNED) in 2018, as a first step in the process of analysing the educational practices in the online courses we teach. The paper explains the CoI model, some studies that have validated the survey in different languages, and the validation we have developed at UNED. We conclude with a discussion and future studies we aim to undertake as a follow-up of this project.
\end{abstract}

\section{Introduction}

Between March and December 2018, within the frame of the CO-Lab Teaching Innovation Group at the Universidad Nacional de Educación a Distancia (UNED), we undertook a research and teaching innovation project, funded by the Vice-Rectorate for Methodology and Innovation. The project was focused on the analysis, using the Community of Inquiry (CoI) theoretical model, of the educational practices developed in 25 Bachelor and Master distance courses in the Faculties of Education and Philosophy, with the aim of making proposals for improvement based on the analysis. We used the CoI survey (Arbaugh et al., 2008), originally developed in English. Its application in our case required a translation into Spanish and adaptation to the UNED context. Hence, one of our objectives was to undertake this task and validate the internal consistency of the CoI survey in the Spanish version.

\section{The Community of Inquiry (Col) model}

The Community of Inquiry model (CoI), based on socio-constructivism, has been widely used in online education. An educational community of inquiry is a group of individuals who collaboratively engage in purposeful critical discourse and reflection to construct personal meaning and confirm mutual understanding (The Community of Inquiry, 2017). Thus, an online higher education course, a MOOC, etc. can be considered communities of inquiry.

The Community of Inquiry conceptual framework represents a process of creating a deep and meaningful (collaborative-constructivist) learning experience through the development of three interdependent elements: social, cognitive and teaching presence (The Community of Inquiry, 2017), as shown in Figure 1. 


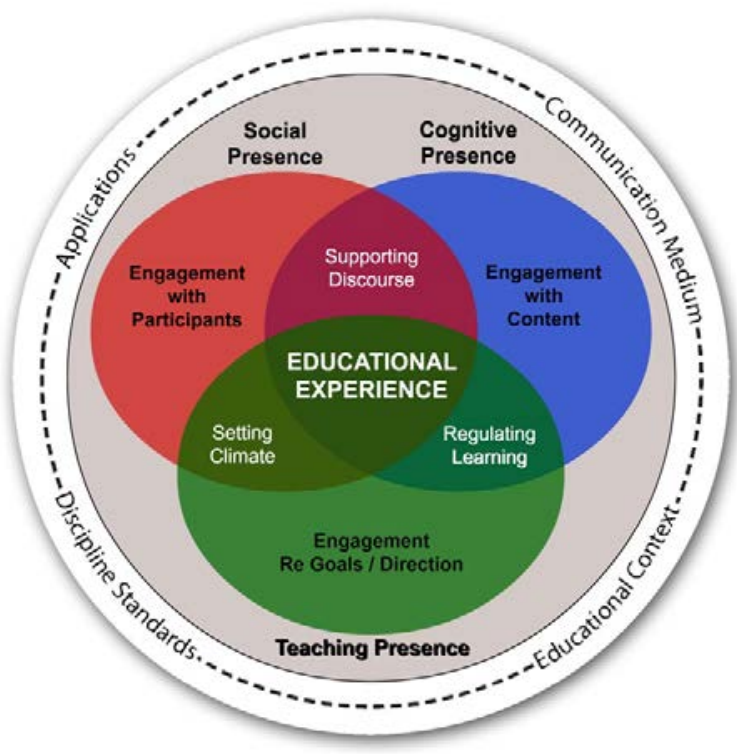

Figure 1: The Community of Inquiry model (http://www.thecommunityofinquiry.org/content/images/diagram.coi.jpg)

The CoI model is composed by 3 interrelated presences:

- Social presence: the ability of learners to project their personal characteristics into the community of inquiry, thereby presenting themselves as "real people". It refers to interaction with peers.

- Cognitive presence: the extent to which the participants are able to construct meaning through sustained communication. It refers to interaction with content.

- Teaching presence: the design, facilitation, and direction of cognitive and social processes for the purpose of realising personally meaningful and educational worthwhile learning outcomes. It refers to interaction with the teachers and/or their directions.

The key to the model, as one of its authors emphasises (Anderson, 2016), is its simplicity (since it includes only three large dimensions, but which interact, as shown in Figure 1) and its ease of use by teachers and researchers.

\section{Validation of the Community of Inquiry (Col) survey}

The CoI survey is 34-items questionnaire which sought to reflect to what extent the three dimensions or interdependent presences (teacher, social and cognitive) were perceived by students in their learning experiences on digital platforms, based on constructivist and collaborative approaches of the CoI model. The survey uses a Likert-type scale.

\section{Previous validation studies}

The validation of the CoI survey in different contexts of distance learning offers, as a general result, the verification of the theoretical structure of the instrument, as well as a high reliability from the point of view of its internal consistency. In table 1 we synthesise the contributions of the five validation studies we have analysed. 
Table 1: Col survey validation studies

\begin{tabular}{|c|c|c|c|c|}
\hline Reference & $\begin{array}{c}\text { Country and } \\
\text { language }\end{array}$ & Method & Sample & Results \\
\hline $\begin{array}{l}\text { Arbaugh } \\
\text { et al. (2008) }\end{array}$ & $\begin{array}{l}\text { USA \& Canada } \\
\text { /English }\end{array}$ & $\begin{array}{l}\text { Construct: analysis } \\
\text { of main } \\
\text { components }\end{array}$ & $\begin{array}{l}287 \text { postgraduate } \\
\text { students in } 4 \\
\text { universities }\end{array}$ & $\begin{array}{l}\text { Verification of the } 3 \\
\text { theoretical factors } \\
\text { but identification of a } \\
4^{\text {th }} \text { factor }\end{array}$ \\
\hline $\begin{array}{l}\text { Swan et al. } \\
(2008)\end{array}$ & $\begin{array}{l}\text { USA \& Canada } \\
\text { /English }\end{array}$ & $\begin{array}{l}\text { Construct: analysis } \\
\text { of main } \\
\text { components } \\
\text { Reliability: internal } \\
\text { consistency }\end{array}$ & $\begin{array}{l}287 \text { postgraduate } \\
\text { distance students } \\
\text { in } 4 \text { universities }\end{array}$ & $\begin{array}{l}\text { Verification of the } \\
\text { theoretical structure } \\
\text { High reliability }\end{array}$ \\
\hline $\begin{array}{l}\text { Yu \& } \\
\text { Richardson } \\
(2015)\end{array}$ & $\begin{array}{l}\text { South Korea / } \\
\text { Korean }\end{array}$ & $\begin{array}{l}\text { Construct: } \\
\text { exploratory factor } \\
\text { analysis } \\
\text { Reliability: internal } \\
\text { consistency }\end{array}$ & $\begin{array}{l}995 \text { students in a } \\
\text { distance university }\end{array}$ & $\begin{array}{l}\text { Verification of the } \\
\text { theoretical structure } \\
\text { High reliability }\end{array}$ \\
\hline $\begin{array}{l}\text { Kovanović } \\
\text { et al. (2018) }\end{array}$ & $\begin{array}{l}\text { USA, India, UK \& } \\
\text { The Netherlands } \\
\text { / English }\end{array}$ & $\begin{array}{l}\text { Construct: } \\
\text { exploratory factor } \\
\text { analysis } \\
\text { Reliability: internal } \\
\text { consistency }\end{array}$ & $\begin{array}{l}1487 \text { MOOC } \\
\text { learners }\end{array}$ & $\begin{array}{l}\text { Verification of the } \\
\text { theoretical structure } \\
\text { High reliability }\end{array}$ \\
\hline $\begin{array}{l}\text { Olpak \& Kiliç } \\
(2018)\end{array}$ & Turkey / Turkish & $\begin{array}{l}\text { Construct: } \\
\text { exploratory and } \\
\text { confirmatory } \\
\text { factor analysis } \\
\text { Reliability: internal } \\
\text { consistency }\end{array}$ & $\begin{array}{l}1150 \text { students in } \\
\text { online courses in } 3 \\
\text { universities }\end{array}$ & $\begin{array}{l}\text { Verification of the } \\
\text { theoretical structure } \\
\text { High reliability }\end{array}$ \\
\hline
\end{tabular}

\section{Validation of the Spanish version of the Col survey}

The original CoI survey is an open resource with a Creative Commons license (CC-BY-SA), available on the CoI website (Garrison, 2011). In accordance with the terms of the license, we have adapted the questionnaire and, published and distributed the Spanish version with a similar license, CC-BY-SA, in a journal article (Ballesteros, Gil-Jaurena, \& Morentin, 2019).

The Spanish version of the survey we have adapted consists of 34 questions with a Likert rating scale of 1 to 5 points. Thirteen questions correspond to the teaching presence, nine to the social presence and twelve to the cognitive presence (similarly to the original survey in English).

We converted the survey into an online form using Google forms, and distributed it through 25 online courses (Undergraduate and Master level). We collected 162 students' replies, 75\% of them female students (in accordance with the profile of the students in the Faculty of Education). The average age was 37 years old. The majority (76.5\%) were studying a Bachelor programme. The validation process is shown in Table 2. 
Validation of the Community of Inquiry Survey (Spanish Version) at UNED Courses

Inés Gil-Jaurena et al.

Table 2: Col survey validation study at UNED

\begin{tabular}{|c|c|c|c|c|}
\hline Reference & $\begin{array}{c}\text { Country and } \\
\text { language }\end{array}$ & Method & Sample & Results \\
\hline $\begin{array}{l}\text { Ballesteros, Gil- } \\
\text { Jaurena, \& Morentin } \\
\text { (2019) }\end{array}$ & $\begin{array}{l}\text { Spain / } \\
\text { Spanish }\end{array}$ & $\begin{array}{l}\text { Construct: } \\
\text { exploratory factor } \\
\text { analysis } \\
\text { Reliability: internal } \\
\text { consistency }\end{array}$ & $\begin{array}{l}162 \\
\text { students }\end{array}$ & $\begin{array}{l}\text { Verification of the } \\
\text { theoretical structure } \\
\text { High reliability }\end{array}$ \\
\hline
\end{tabular}

Construct validity was analysed through exploratory factor analysis. The results of the matrix of rotated factor structure (Table 3) show the achievement of a discrepancy between the saturations in the first two factors above $.50 / .20$ or $.60 / .20$, that is, a difference of $.30-.40$, which indicates the adjustment of the dimensions to the theoretical structure.

In Table 3, we keep the items in Spanish. The English version can be found in the CoI website: https://coi.athabascau.ca/coi-model/coi-survey/

Table 3: Factor structure matrix, Col survey Spanish version

\begin{tabular}{|c|c|c|c|}
\hline & $\begin{array}{l}\text { Teaching } \\
\text { presence }\end{array}$ & $\begin{array}{c}\text { Social } \\
\text { presence }\end{array}$ & $\begin{array}{l}\text { Cognitive } \\
\text { presence }\end{array}$ \\
\hline $\begin{array}{l}\text { El profesorado ha comunicado con claridad los } \\
\text { contenidos de la asignatura }\end{array}$ & .864 & .215 & .617 \\
\hline $\begin{array}{l}\text { El profesorado ha comunicado con claridad los } \\
\text { objetivos de la asignatura }\end{array}$ & .820 & .225 & .670 \\
\hline $\begin{array}{l}\text { El profesorado ha facilitado instrucciones claras acerca } \\
\text { de cómo realizar las actividades de aprendizaje }\end{array}$ & .798 & .246 & .626 \\
\hline $\begin{array}{l}\text { El profesorado ha informado claramente de los plazos } \\
\text { de realización y las fechas de entrega de las actividades }\end{array}$ & .516 & .236 & .455 \\
\hline $\begin{array}{l}\text { El profesorado ha facilitado la identificación de aspectos } \\
\text { polémicos y diferentes perspectivas en los contenidos }\end{array}$ & .859 & .342 & .665 \\
\hline $\begin{array}{l}\text { El profesorado ha orientado la actividad del grupo } \\
\text { facilitando la comprensión de los temas de forma tal } \\
\text { que me ayudó a aclarar mis ideas }\end{array}$ & .873 & .337 & .690 \\
\hline $\begin{array}{l}\text { El profesorado ha propiciado la implicación y la } \\
\text { participación de los/las estudiantes en debates } \\
\text { productivos }\end{array}$ & .865 & .365 & .518 \\
\hline $\begin{array}{l}\text { El profesorado ha mantenido a los/las estudiantes } \\
\text { centrados en las tareas de forma tal que facilitó el } \\
\text { aprendizaje }\end{array}$ & .921 & .361 & .651 \\
\hline $\begin{array}{l}\text { El profesorado ha animado a los/las estudiantes a } \\
\text { explorar nuevos conceptos }\end{array}$ & .878 & .275 & .607 \\
\hline $\begin{array}{l}\text { Las aportaciones del profesorado han promovido el } \\
\text { sentido de pertenencia al grupo }\end{array}$ & .857 & .392 & .537 \\
\hline $\begin{array}{l}\text { El profesorado ha facilitado que los debates se } \\
\text { enfoquen hacia cuestiones relevantes }\end{array}$ & .897 & .317 & .579 \\
\hline $\begin{array}{l}\text { El profesorado ha respondido con comentarios que me } \\
\text { ayudaron a entender mis puntos fuertes y débiles en } \\
\text { relación con los objetivos de la asignatura }\end{array}$ & .860 & .293 & .667 \\
\hline $\begin{array}{l}\text { El profesorado ha ofrecido respuestas adecuadas } \\
\text { (feedback) en los momentos oportunos }\end{array}$ & .867 & .255 & .609 \\
\hline
\end{tabular}




\begin{tabular}{|c|c|c|c|}
\hline $\begin{array}{l}\text { Conocer a otros/as compañeros/as hizo que me sintiera } \\
\text { parte del grupo }\end{array}$ & .095 & .655 & .276 \\
\hline $\begin{array}{l}\text { He podido conocer un poco más a fondo a algunos/as } \\
\text { de los/las compañeros/as del curso }\end{array}$ & .105 & .642 & .346 \\
\hline $\begin{array}{l}\text { La comunicación digital (online) es un medio excelente } \\
\text { para la interacción social }\end{array}$ & .137 & .635 & .317 \\
\hline $\begin{array}{l}\text { Me he sentido cómodo/a conversando a través de la } \\
\text { plataforma digital }\end{array}$ & .489 & .763 & .391 \\
\hline $\begin{array}{l}\text { Me he sentido cómodo/a participando en los debates } \\
\text { de la asignatura }\end{array}$ & .558 & .794 & .481 \\
\hline $\begin{array}{l}\text { Me he sentido cómodo/a interactuando con los/las } \\
\text { compañeros/as de la asignatura }\end{array}$ & .277 & .888 & .321 \\
\hline $\begin{array}{l}\text { Me he sentido cómodo/a manifestando mi desacuerdo } \\
\text { con otros/as compañeros/as en un clima de confianza }\end{array}$ & .349 & .874 & .389 \\
\hline $\begin{array}{l}\text { He sentido que mi punto de vista era reconocido por } \\
\text { otros/as compañeros/as }\end{array}$ & .279 & .825 & .304 \\
\hline $\begin{array}{l}\text { Los debates en la plataforma me han ayudado a } \\
\text { desarrollar un espíritu colaborativo }\end{array}$ & .528 & .800 & .453 \\
\hline $\begin{array}{l}\text { Las problemáticas que se han planteado han } \\
\text { aumentado mi interés en los temas tratados }\end{array}$ & .775 & .368 & .834 \\
\hline Las actividades del curso han despertado mi curiosidad & .678 & .315 & .885 \\
\hline $\begin{array}{l}\text { Me he sentido motivado/a para explorar cuestiones } \\
\text { relacionadas con los contenidos }\end{array}$ & .720 & .355 & .867 \\
\hline $\begin{array}{l}\text { He utilizado diversas fuentes de información para } \\
\text { explorar las cuestiones que se plantean en la asignatura }\end{array}$ & .411 & .300 & 697 \\
\hline $\begin{array}{l}\text { La búsqueda de información relevante y las ideas } \\
\text { compartidas durante el curso me han ayudado a } \\
\text { responder cuestiones relacionadas con los contenidos }\end{array}$ & .586 & .375 & .869 \\
\hline $\begin{array}{l}\text { Los debates en la plataforma me han ayudado a valorar } \\
\text { perspectivas diversas }\end{array}$ & .579 & .603 & .626 \\
\hline $\begin{array}{l}\text { La integración de nueva información me ha ayudado a } \\
\text { responder a las actividades de la asignatura }\end{array}$ & .630 & .417 & .802 \\
\hline $\begin{array}{l}\text { Las actividades de aprendizaje me han ayudado a } \\
\text { construir explicaciones y soluciones }\end{array}$ & .665 & .302 & .891 \\
\hline $\begin{array}{l}\text { La reflexión sobre los contenidos y los debates me han } \\
\text { ayudado a comprender los conceptos fundamentales } \\
\text { de la asignatura }\end{array}$ & .671 & .415 &.$\varepsilon$ \\
\hline $\begin{array}{l}\text { Soy capaz de describir formas de contrastar y aplicar los } \\
\text { conocimientos generados en la asignatura }\end{array}$ & .586 & .325 & .761 \\
\hline $\begin{array}{l}\text { He encontrado soluciones a problemas propios de la } \\
\text { asignatura que pueden aplicarse en la práctica }\end{array}$ & .520 & .449 & .8 \\
\hline $\begin{array}{l}\text { Soy capaz de aplicar el conocimiento generado en la } \\
\text { asignatura en mi trabajo o en otras actividades ajenas a } \\
\text { la asignatura }\end{array}$ & .482 & .389 & .806 \\
\hline
\end{tabular}

Reliability was analysed from the internal consistency approach, using the Cronbach alpha statistic. The results show values of $0.921,0.926$ and 0.938 in the teaching, social and cognitive dimensions, respectively, so we can justify that the CoI survey in its Spanish version has a high level of reliability and can be used as a measuring instrument in other studies. 


\section{Discussion and conclusions}

The study of the technical characteristics of the CoI survey (Spanish version) supports its use as an instrument of measurement in educational research. The construct validity through the exploratory factor analysis allows to identify the teaching, social and cognitive presences, according to the theoretical basis that sustains the instrument. On the other hand, the results of the analysis of the internal consistency show a high reliability.

Further analyses are explained in Ballesteros, Gil-Jaurena, and Morentin (2019). Among them, we highlight the correlation between the 3 factors, which suggests a remarkable correlation between the teaching and cognitive presences, while the social factor shows a low correlation with the other two components. These results contrast with the theory on which the CoI survey is based (Figure 1); the CoI model indicates an interdependence between the three factors. This has led us to review the way in which the items are formulated within each factor in the survey, particularly the social dimension, which additionally is the one that shows the lowest scores in the courses we have analysed (Gil-Jaurena et al., 2018). The way the social presence items are stated in the survey poses a self-assessment of the students on feelings arising in the process of learning, without clearly visualising the role of the teacher. That is, these social presences related items are closer to an emotional perspective, centred on the student, than to the social approach promoted by the teacher.

In future studies, we aim to further explore the social dimension, either it happens within or beyond the virtual platform we use in the courses. Social connection and interactions between learners and its role in the learning process will be the focus of our next study in the CO-Lab teaching innovation group at UNED.

\section{References}

Anderson, T. (2016, January 4). A Fourth Presence for the Community of Inquiry Model? Virtual Canuck [Blog post]. Retrieved from http://virtualcanuck.ca/2016/01/04/a-fourthpresence-for-the-community-of-inquiry-model

Arbaugh, J. B., Cleveland-Innes, M., Diaz, S. R., Garrison, D. R., Ice, P., Richardson, \& Swan, K. P. (2008). Developing a community of inquiry instrument: Testing a measure of the Community of Inquiry framework using a multi-institutional sample. The Internet and Higher Education, 11(3-4), 133-136. https://doi.org/10.1016/j.iheduc.2008.06.003

Ballesteros, B., Gil-Jaurena, I., \& Morentin, J. (2019). Validación de la versión en castellano del cuestionario 'Community of Inquiry'. Revista de Educación a Distancia - RED, 59.

Garrison, D. R. (2011). About the Framework. An introduction to the Community of Inquiry. The Community of Inquiry. Retrieved from http://www.thecommunityofinquiry.org/coi

Gil-Jaurena, I., Domínguez, D., Izquierdo, A., \& Morentin, J. (2018). Análisis de cursos online y a distancia desde el modelo "Community of Inquiry". In J. Valverde-Berrocoso (Ed.), Campus Digitales en la Educación Superior. Experiencias e investigaciones (pp. 346-356), Cáceres, Spain: Universidad de Extremadura. 
Kovanović, V., Joksimović, S., Poquet, O., Hennis, T., Čukić, I., Vries, P., Hatalae, M., Dawson, S., Siemens, G., \& Gašević, D. (2018). Exploring communities of inquiry in Massive Open Online Courses. Computer \& Education, 119, 44-58. https://doi.org/10.1016/j.compedu.2017.11.010

Olpak, Y. Z., \& Kiliç Çakmak, E. (2018). Examining the Reliability and Validity of a Turkish Version of the Community of Inquiry Survey. Online Learning, 22(1). http://dx.doi.org/10.24059/olj.v22i1 1990

Swan, K. P., Richardson, J. C., Ice, P., Garrison, D. R, Cleveland-Innes, M., \& Arbaugh, J. B. (2008). Validating a Measurement Tool of Presence in Online Communities of Inquiry. Ementor, 2(24). Retrieved from http://www.e-mentor.edu.pl/_xml/wydania/24/543.pdf

The Community of Inquiry (2017). About the model. Athabasca University. Retrieved from http://www.thecommunityofinquiry.org/coi

Yu, T., \& Richardson, J. (2015). Examining reliability and validity of a Korean version of the Community of Inquiry instrument using exploratory and confirmatory factor analysis.

The Internet and Higher Education, 25, 45-52. https://doi.org/10.1016/j.iheduc.2014.12.004

\section{Acknowledgments}

This work was supported by the educational innovation project "Use of the Community of Inquiry (CoI) model in the analysis and evaluation of courses at UNED (Spain)", Ref. GID2016-30, funded by the UNED Vice-Rectorate for Methodology and Innovation (2018). 